\title{
Phytochemical Screening and Evaluation of Cytotoxic Effect and Antioxidant Activity of Fractions Isolated from Stenochlaena palustri (Burm.f.) Bedd. Leaves
}

\author{
Sangeetha Arullappan*, Sakunie Sawai, Lew Ann Chee, Meerashri Mahandan, \\ Ragaventhan Shanmugavelan
}

Faculty of Science, Universiti Tunku Abdul Rahman, Bandar Barat, Jalan University, 31900 Kampar, Perak, MALAYSIA.

\begin{abstract}
Introduction: Stenochlaena palustris (Burm.f.) Bedd. is an edible fern from Blechnaceae family, native to India through Southeast Asia to Polynesia and Australia. The study was conducted to evaluate the cytotoxic effect and antioxidant activity of fractions obtained from Stenochlaena palustris leaf extracts. Methods: Stenochlaena palustris (Burm.f.) Bedd. was tested for its antioxidant activity using DPPH assay and in vitro cytotoxic effect against HeLa cancer cell line using MTT assay. Major fractions were obtained from ethanol and ethyl acetate leaves extract of Stenochlaena palustris (Burm.f.) Bedd. through gravity column chromatography and the secondary metabolites were screened using qualitative phytochemical analysis. Results: In DPPH assay, the highest radical scavenging activity was exhibited by fraction 11 of ethanol extract and fraction 4 of ethyl acetate extract at $98.47 \pm 0.002 \%\left(E_{50}=0.120 \mathrm{mg} / \mathrm{mL}\right)$, and $81.38 \pm 0.018 \%$ $\left(E D_{50}=0.650 \mathrm{mg} / \mathrm{mL}\right)$, respectively. Meanwhile, ascorbic acid and kaempferol exhibited radical scavenging of $80.95 \pm 0.002 \%\left(E D_{50}=0.014 \mathrm{mg} / \mathrm{mL}\right)$ and $98.67 \pm 0.006 \%$ $\left(E D_{50}=0.011 \mathrm{mg} / \mathrm{mL}\right)$. As for MTT assay, the percentages of cell viability of both cell lines decreased as the concentration increased. Fraction 7 of ethanol extract and fraction 1 of ethyl acetate extract exhibited the lowest $\mathrm{IC}_{50}$ value of $4.58 \mu \mathrm{g} / \mathrm{mL}$ and $8.60 \mu \mathrm{g} / \mathrm{ml}$, respectively. Doxorubicin hydrochloride showed lowest $I_{50}$ value of $2.21 \mu \mathrm{g} / \mathrm{mL}$ against HeLa cells. Conclusion: The fractions isolated from ethanol and ethyl acetate leaves extract of Stenochlaena palustris (Burm.f.) Bedd. exhibited higher cytotoxic effect against HeLa cells, and higher radical scavenging activity.
\end{abstract}

Key words: Stenochlaena palustris (Burm.f.) Bedd, Phytochemical analysis, DPPH and MTT assays.

\section{INTRODUCTION}

Stenochlaena palustris (Burm.f.) Bedd. Islands, south and northern Australia, islands or commonly known as 'pucuk midin' or 'Kelakai among the Malays,' is a climbing fern with long-creeping rhizome, 0.5 to $1.0 \mathrm{~cm}$ in diameter, green in colour, but turns brownish upon maturity. S. palustris is an adaptable species, commonly found at the edges of hot springs, mangroves and fresh water at forest margins. Furthermore, the fern is found growing on a wide range of tress and palms. ${ }^{2}$ It is widely distributed throughout Malaysia, India, Myanmar, Yunnan in China, Laos, Thailand, Vietnam, Solomon of Fiji, Samoa and Tonga. ${ }^{3}$ This species is also present in East Africa as well as on the Indian Ocean islands such as Madagascar. ${ }^{4}$ The reddish young fronds are harvested from the wild and eaten as vegetables in countries like Malaysia, Thailand, Philippines, and Indonesia. In Malaysia, the plant is taken raw or cooked with boiling water in treating diarrhoea, while in Sumatra it is used as mild laxative. ${ }^{1}$ In Nicobar Islands and the central region of Papua New Guinea, the tender leaves of $S$. palustris are used as a
Submission Date: 19-09-2017; Revision Date: 12-10-2017; Accepted Date: 23-11-2017

DOI: 10.5530/ijper.51.4s.106 Correspondence: MS. Sangeetha Arullappan, Faculty of Science, Universiti Tunku Abdul Rahman, Bandar Barat, Jalan University, 31900 Kampar, Perak, MALAYSIA.

Phone no: +60166662512; Fax: +6054661676 E-mail: sangeetha@utar. edu.my

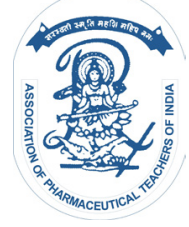

www.ijper.org 
contraceptive. ${ }^{5}$ The juice of the fern can help treating fever. In Malaysia and Indonesia, the fern is made into paste and applied on the ulcers, wound injuries and bacterial infected skin. ${ }^{3}$

The objectives of the study were to isolate semi-purified fractions from ethanol and ethyl acetate crude extracts of Stenochlaena palustris and to determine its antioxidant activity and cytotoxic effect against selected cancer cell lines. The study also qualitatively screened possible secondary metabolites presence, such as flavonoids, alkaloids, phenols, saponins, terpenoids, quinones, glycosides and tannins.

\section{EXPERIMENTAL}

\section{Plant materials}

Stenocblaena palustris leaves $(4.0 \mathrm{~kg})$ were collected from a swampy land at Cherang Ruku, Pasir Puteh, Kelantan, Malaysia (Coordinate: $5.8710843,102.4832757$ ) on $3^{\text {rd }}$ of June 2014. The plant was authenticated by Dr. Goh Teik Khiang, Department of Agriculture and Food Science, UTAR, Perak. A voucher specimen (140615) was kept at the Biomedical Science Laboratory, University Tunku Abdul Rahman, and Malaysia. The matured leaves were air dried and were crushed into powdered form. The powdered leaves were soaked ethyl acetate and ethanol $(95 \%)$, respectively and the filtrates were concentrated using rotary evaporator at 40 to $60^{\circ} \mathrm{C}$ (R-200, Buchi). This step was repeated twice with soaking period of three days. The weights of ethanol extract were 53.07 $\mathrm{g}$, meanwhile ethyl acetate was $9.20 \mathrm{~g}$ and these extracts were kept at $4^{\circ} \mathrm{C}$.

\section{Phytochemical screening}

Test for the presence of flavonoids, alkaloids, phenols, saponins, terpenoids, quinones, glycosides and tannins in the crude extracts of Stenochlaena palustris leaves were carried out using modified methods. ${ }^{6,7}$

\section{Gravity column chromatography}

The ethyl acetate and ethanol extracts, respectively were added to column $(4 \mathrm{~cm} \times 50 \mathrm{~cm})$ containing packed silica (silica was added approximately $2 / 3$ height of the column for better separation). Hexane $(100 \%)$ was first flowed through the column and the polarity of the solvent was slowly increased using various combinations of solvents such as hexane: ethyl acetate, methanol, and ethanol. Examples of gradients system used are hexane: ethyl acetate (10:1; 10:2, 10:3, and increasing), ethyl acetate alone $(100 \%)$, followed by ethyl acetate: methanol (10:1; 10:1.5 and increasing), finally were flushed out with only methanol (100\%). Approximately $200 \mathrm{~mL}$ of eluate was collected and concentrated using rotary evaporator. The 50 fractions obtained were subjected to thin layer chromatography (TLC) for combination of similar compounds. These fractions were dried in the oven at $37^{\circ} \mathrm{C}$ and the dry weights of the fractions were tabulated as Table $1 \mathrm{~A}$.

\section{Cell culture and subculture}

Human epithelial carcinoma cell line, HeLa (ATCC ${ }^{\circ} C C L-2^{\mathrm{TM}}$ ) was cultured using Dulbecco's Modified Eagle Medium (DMEM) supplemented with $10 \%$ foetal bovine serum (FBS) (JR Scientific, Inc, USA) and incubated in $5 \% \mathrm{CO}_{2}$ incubator (BINDER, Germany) at $37^{\circ} \mathrm{C}$. The cells were sub cultured upon reaching $80 \%$ confluency. HeLa cells were trypsinised using trypsinEDTA (0.25\%) (Sigma, USA) for 10 min. Once cells detached, complete medium was added to the cells to deactivate the trypsin activity. The mixture was then centrifuged at $1000 \mathrm{rpm}$ for $10 \mathrm{~min}$. The supernatants were removed, and the pellets were re-suspended with complete medium. The cells were then aliquoted to few culture flasks containing complete medium and incubated in $5 \% \mathrm{CO}_{2}$ incubator.

\section{DPPH assay}

Stock samples of fractions obtained from both extracts were prepared at $10 \mathrm{mg} / \mathrm{mL}$ using absolute methanol (acetone-free). DPPH assay was conducted using 96-well microliter plate. Approximately $150 \mu \mathrm{L}$ of methanol (analytical grade) were added into the 96-well plate. Later, $50 \mu \mathrm{L}$ ascorbic acid, kaempferol and fractions, respectively were added into the well and were further diluted to obtain concentrations ranging from 0.16 to $5.00 \mathrm{mg} / \mathrm{mL}$. Methanol was used as negative control. Fifty microliter of $0.2 \mathrm{mM} \mathrm{DPPH}$ reagent (SigmaAldrich, USA) was added into each well and incubated at room temperature in dark for $30 \mathrm{~min}$. After incubation, the absorbance was read at $517 \mathrm{~nm}$ using microliter plate reader (Tecan, USA). These steps were repeated for thrice and the average absorbance values were calculated. The percentage of radical scavenging activity was calculated based on the following formula and graph of percentage of radical scavenging against concentration were plotted. ${ }^{8}$

Percentage of radical scavenging $=\left[\left(\mathrm{A}_{\mathrm{NC}}-\mathrm{A}_{\text {sample }}\right) /\right.$ $\left.A_{N C}\right] \times 100 \%$ : where, $A_{N C}=$ average absorbance of negative control; $\mathrm{A}_{\text {sample }}=$ average absorbance of sample.

\section{MTT Assay}

The fractions were prepared at $10 \mathrm{mg} / \mathrm{mL}$ using 100\% DMSO (Merck, Germany) and were further diluted with basic medium at various concentrations ranging from 6.25 to $100.00 \mu \mathrm{g} / \mathrm{mL}$. The DMSO content in MTT 


\begin{tabular}{|c|c|c|c|}
\hline \multicolumn{5}{|c}{ Table 1A: Fractions collected from ethanol and ethyl acetate extracts, respectively via gravity } \\
column chromatography. & Weight(g) \\
\hline $\begin{array}{c}\text { Fractions collected from ethanol } \\
\text { crude extract }\end{array}$ & Weight(g) & $\begin{array}{c}\text { Fractions collected from ethyl } \\
\text { acetate crude extract }\end{array}$ & 0.10 \\
\hline 1 & 0.10 & 1 & 0.07 \\
\hline 2 & 0.07 & 2 & 0.07 \\
\hline 3 & 0.10 & 3 & 0.46 \\
\hline 4 & 0.09 & 4 & 0.36 \\
\hline 5 & 0.24 & 5 & 0.08 \\
\hline 6 & 0.06 & 6 & 0.77 \\
\hline 7 & 0.08 & 7 & 0.14 \\
\hline 8 & 0.03 & 8 & 0.34 \\
\hline 9 & 0.07 & 9 & 0.07 \\
\hline 10 & 0.06 & 10 & 0.10 \\
\hline 11 & 0.10 & 11 & 0.11 \\
\hline 12 & 0.07 & 12 & 0.15 \\
\hline 13 & 0.08 & 13 & 0.22 \\
\hline 14 & 0.13 & 14 & 0.20 \\
\hline 15 & 0.22 & 15 & 0.51 \\
\hline 16 & $\mathbf{0 . 4 1}$ & 16 & 0.04 \\
\hline 17 & 0.17 & 17 & 0.32 \\
\hline 18 & 0.17 & 18 & \\
\hline & & & 5 \\
\hline
\end{tabular}

Table 1B: Phytochemical results of the ethanol and ethyl acetate leaves extracts of Stenochlaena

\begin{tabular}{|c|c|}
\hline \multicolumn{2}{|c|}{ palustris. } \\
\hline Metabolites & Observation \\
\hline Alkaloids & +++ \\
\hline Flavonoids & +++ \\
\hline Phenols & +++ \\
\hline Saponins & +++ \\
\hline Terpenoids & ++ \\
\hline Quinones & - \\
\hline Glycosides & + \\
\hline Tannins & + \\
\hline
\end{tabular}

+++ Higher amount; ++ moderate amount; + lesser amount; - not detected

assay was $<1 \%$. The concentration of cells used was $1.0 \times 10^{5}$ cells $/ \mathrm{mL}$. Approximately, $100 \mu \mathrm{L}$ of respective cells were seeded into the 96-well plate and incubated in $5 \% \mathrm{CO}_{2}$ incubator for $24 \mathrm{~h}$. About $50 \mu \mathrm{L}$ of fractions, doxorubicin (Fisher Scientific, USA) and 1\% DMSO were added into respective wells. The cells were incubated for $72 \mathrm{~h}$. MTT reagent $(5 \mathrm{mg} / \mathrm{mL})(20 \mu \mathrm{L})$ was added into the wells and incubated further for $4 \mathrm{~h}$. After incubation, $200 \mu \mathrm{L}$ of $100 \%$ DMSO was added into the wells. The colour changes from yellow to purple were observed and the absorbance was read at $570 \mathrm{~nm}$ using microliter plate reader (Tecan, USA). The graphs of percentage of cell viability against concentration were plotted and the $\mathrm{IC}_{50}$ values were determined from the graph. Percentage of cell viability was calculated using the formula:

Percentage of cell viability $=\left(\mathrm{A}_{\text {sample }} / \mathrm{A}_{\mathrm{NC}}\right) \times 100 \%$; Where, $\mathrm{A}_{\text {sample }}=$ average absorbance of the sample, $\mathrm{A}_{\mathrm{NC}}$ $=$ average absorbance of the negative control. ${ }^{9}$ MTT assay was repeated thrice.

\section{Data analysis}

The data obtained from both assays were tabulated and analysed using Microsoft Office Excel 2013. The results are expressed as mean values and standard deviation (SD). P $<0.05$ was considered statistically significant.

\section{RESULTS}

\section{Phytochemical Screening}

The presence of several secondary metabolites such as alkaloids, flavonoids, phenols, saponins, terpenoids, glycosides and tannins were detected in fractions obtained from both extracts Table 1B. These major metabolites were detected based on colour changes, 

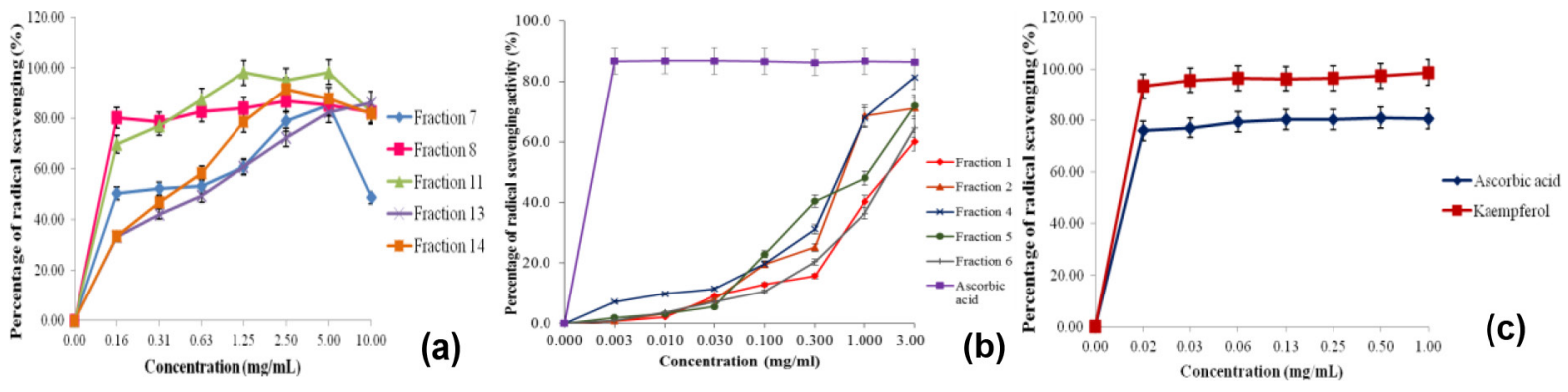

Figure 1: The percentage radical scavenging activity of samples at various concentrations (a) Fractions $7,8,11,13$ and 14 isolated from ethanol extract; (b) Fractions 1, 2, 4, 5 and 6 from ethyl acetate extract; (c) Ascorbic acid and kaempferol.

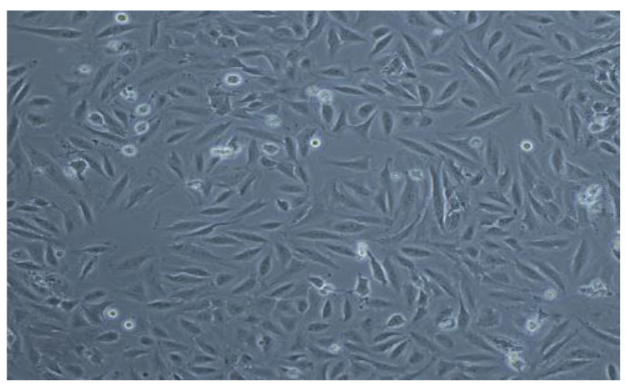

(a)

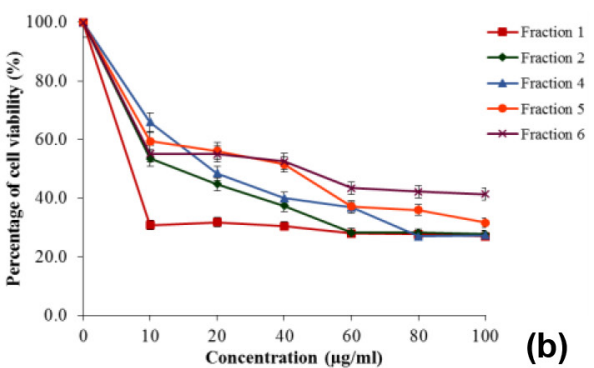

(b)
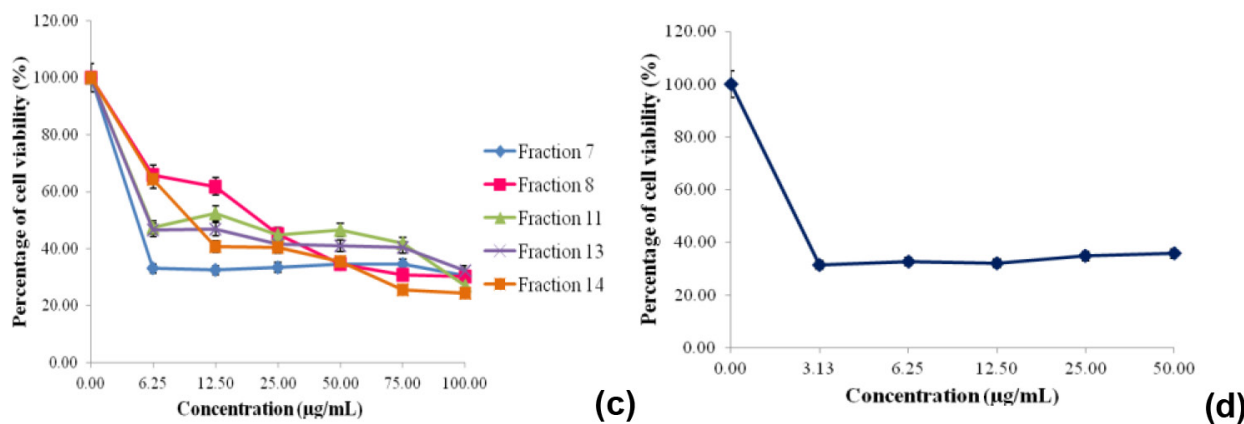

Figure 2: (a) Morphology of HeLa cancer cell lines cultured in DMEM at 80 to $90 \%$ confluency under magnification of 100x; The percentage viability of HeLa cells at $72 \mathrm{~h}$ incubation using different concentration of (b) fractions 1, 2, 4, 5 and 6 of ethyl acetate extract, (c) Fractions 7, 8, 11, 13 and 14 of ethanol extract, (d) Doxorubicin hydrochloride.

formation of precipitation or formation of persistent forms qualitatively. A reddish-brown precipitate was formed to confirm the presence of alkaloids in all the fractions. Besides, higher amount of saponins, flavonoids and phenols were also detected. On the other hand, lower number of glycosides and tannins were identified. No quinones were detected in the qualitative phytochemical screening.

\section{DPPH assay}

Few selected fractions from both extracts and positive controls showed higher radical scavenging activity as the concentration increases. Fractions 7, 8, 11, 13 and 14 from ethanol extract exhibited higher radical scavenging activity, and among them fraction 11 showed $98.47 \%$ at
$5.00 \mathrm{mg} / \mathrm{mL}$. The $\mathrm{ED}_{50}$ value of fraction 11 was 0.120 $\mathrm{mg} / \mathrm{mL}$.

Meanwhile, fractions 1, 2, 4, 5 and 6 from ethyl acetate extract showed potential radical scavenging activity. Fraction 4 exhibited the highest radical scavenging activity of $81.38 \%$ at $3.000 \mathrm{mg} / \mathrm{ml}$, followed by fraction 5 with $71.90 \%$. The $\mathrm{Ed}_{50}$ value of fraction 4 is 0.650 $\mathrm{mg} / \mathrm{mL}$. Positive controls, kaempferol and ascorbic acid showed $98.67 \%$ and $80.95 \%$, respectively Figure 1.

\section{MTT assay}

Confluent HeLa cells as shown in Figure 2(A) were used in MTT assay. The percentage viability of HeLa cells decreased as the concentration of fractions increased and there was a slight fluctuation in between the concentrations Figure 2 (B) and (C). Fractions 1 and 
4 of ethyl acetate extract exhibited the lowest cell viability against $\mathrm{HeLa}$ cells upon treatment with $26.90 \%$ $\left(\mathrm{IC}_{50}: 8.60 \mu \mathrm{g} / \mathrm{mL}\right.$ ) and $26.92 \%\left(\mathrm{IC}_{50}: 19.40 \mu \mathrm{g} / \mathrm{mL}\right)$, respectively. Meanwhile, Fractions 13 and 14 of ethanol extract showed cell viability of $32.39 \%\left(\mathrm{IC}_{50}: 5.83 \mu \mathrm{g} / \mathrm{mL}\right)$ and $24.43 \%\left(\mathrm{IC}_{50}: 10.16 \mu \mathrm{g} / \mathrm{mL}\right)$, respectively. The $\mathrm{IC}_{50}$ values obtained for all the fractions were less than 50.00 $\mu \mathrm{g} / \mathrm{mL}$. On the other hand, the $\mathrm{IC}_{50}$ value of doxorubicin hydrochloride was $2.21 \mu \mathrm{g} / \mathrm{mL}$ and killed almost all the HeLa cells Figure 2 (D).

\section{DISCUSSION}

In the presence of antioxidant molecules, the DPPH free radicals will be reduced leading to the changes in colour of DPPH reagent from violet to yellow or colourless. ${ }^{10}$ Fractions obtained from both extracts showed potential antioxidant activity may due to the presence of higher amount of alkaloids, flavonoids and phenols based on qualitative phytochemical screening results. Medini et al. (2014) reported that antioxidant capacity is highly associated with phenolic content and most of the radical scavenging activity of plants is derived from phenols. ${ }^{11}$ The presence of functional groups such as hydroxyl groups, keto groups, conjugated double bonds, $\beta$-ionone ring may contribute to its higher antioxidant activity. ${ }^{12}$ The hydroxyl groups help to reduce the free radicals by donating a hydrogen atom, while hydrophobic side chains allows the metabolites to penetrate into biological membranes. ${ }^{13}$ to exert free radical scavenging activity. Phenolic compounds isolated from plants were known to trigger redox reactions, reduce and stabilise highly oxidising free radicals by donating hydrogen atoms and electrons. ${ }^{14}$

Human cervical cancer cell line (HeLa) is the oldest and most widely used cancer cell line in human structural and molecular studies. HeLa cells exhibited epithelial-like morphology and was inhibited by the fractions isolated from both extracts. The inhibition was evaluated using MT'T assay, a colorimetric assay by quantifying mitochondrial succinate dehydrogenase activity of proliferating cells. ${ }^{15}$ Succinate dehydrogenase is a mitochondrial reductase enzyme that cleaves the tetrazolium ring and catalyses the conversion of water soluble tetrazolium salt to an insoluble purple formazan. Cancer cells are highly proliferating cells and possess high succinate dehydrogenase activities. ${ }^{9}$ Due to the presence of active secondary metabolites in the fractions as reported, HeLa cells possibly may undergo destruction effect either alter its genetic constituents, reducing micro hypoxic environments in tumours or targeting cell cycle that enhance the killing effect on the cancer cells. ${ }^{16}$ Flavonoids were proven as therapeutic agents for cancer prevention as it reduces cancer cells proliferation and significantly decreases the expression angiogenesis marker, vascular endothelial growth factor (VEGF) in ovarian cancer cells. Furthermore, it has been shown to inhibit cell proliferation in a dose dependent manner by regulating cyclin-dependent kinase 1 (CDK1) and cyclin B, a marker for transition of $\mathrm{G} 2$ to $\mathrm{M}$ phase, and by regulating a tumour suppressor gene which plays a key role in cell cycle arrest, p53 in MCF-7 breast cancer and HeLa cervical cancer cells. ${ }^{17}$ Thus, inhibition of Hela cancer cells upon the treatments of various fractions could possibly followed the cell cycle arrest signalling pathway and thus stops the cells from proliferating further.

The bioactive constituents from the fractions isolated from both extracts could be the root factor for a potential cytotoxic agents and antioxidant activity. However, further isolation and purification, followed by structural elucidation may reveal the potential pure compounds that exert its bioactivity.

\section{CONCLUSION}

Fractions obtained from Stenochlaena palustris leaves are potential cytotoxic and antioxidant agents. Therefore, further studies should be carried out to evaluate its bioactivity using pure compounds in developing potential pharmaceutical drugs.

\section{ACKNOWLEDGEMENT}

The authors wished to thank UniversitiTunku Abdul Rahman (UTAR), Kampar, Malaysia for their supports.

\section{CONFLTCIT OF INTEREST}

Authors declare no conflict of interest.

\section{ABBREVIATIONS USED}

HeLa: Human Cervical Cancer Cell Line; MTT: 3-(4,5-dimethylthiazol-2-yl)-2,5-diphenyltetrazolium bromide; DPPH: 1,1-diphenyl-2-picrylhydrazyl; $\mathbf{I C}_{50}$ : Half-maximal inhibitory concentration; $\mathbf{E D}_{50}$ : Halfmaximal effective concentration.

\section{REFERENCES}

1. Chai TT, Panirchellvum E, Ong HC, Wong FC. Phenolic contents and antioxidant properties of Stenochlaena palustris. Botanical Studies. 2012;53:439-46.

2. Chambers TC. A review of the genus Stenochlaena (Blechnaceae, subfamily Stenochlaenoideae). J Plant Sys. 15 2013:13-6.

3. Australian National Botanic Gardens, 2014. Blechnaceae. [online] Available at: <https://www.anbg.gov.au/fern/aquatic/blechnaceae.html> Accessed 2 February. 2015. 
4. Raffles Museum of Biodiversity Research, 2014. Stenochlaena palustris. [online] Available at: <http://lkcnhm.nus.edu.sg/dna/organisms/details/611> Accessed 28 October 2014.

5. Zuraini Z, Sasidharan S, Kaur SR, Nithiyayini M. Antimicrobial and antifungal activities of local edible fern Stenochlaena palustris (Burm. F.) Bedd. Pharmacol. 2010;1:233-7.

6. Ugochukwu SC, Uche A, Ifeanyi O. Preliminary phytochemical screening of different solvent extracts of stem bark and roots of Dennetia tripetala G. Baker. Asian J Plant Sci and Res. 2013;3(3):10-3.

7. Bhandary SK, Kumari NS, Bhat VS, Sharmila KP, Bekal MP. Preliminary phytochemical screening of various extracts of Punica granatum peel, whole fruit and seeds. J Health Sci. 2012;2(4):34-8.

8. Melendez NP, Moorillon VN, Herrera RR, Espinoza JC, Aguilar CN. A microassay for quantification of 2,2-diphenyl-1-picrylhydracyl (DPPH) free radical scavenging. Afr J Biochem Res. 2014;8(1):14-8.

9. Prema R, Sekar DSS, Sekhar KBC, Jeevanandham S. In vitro cytotoxicity study on combined plants extracts (Cissus quadrangularis and Aegle marmelos). Europen J Exp Biol. 2012;2(4):882-8

10. Garcia EJ, Oldoni TLC, Alencar SMD, Reis A, Loguercio AD, Grade RHM. Antioxidant activity by DPPH assay of potential solutions to be applied on bleached teeth. Braz Dent J. 2012;23(1):22-7.
11. Medini F, Fellah H, Ksouri R, Abdelly C. Total phenolic, flavonoid and tannin content and antioxidant and antimicrobial activities of organic extracts of shoots of plant Limonium delicatulum. J Taibah Univ Sci. 2014;8:216-24.

12. Apak R, Gorinstein S, Böhm V, Schaich KM, Özyürek M, Güçlü K. Methods of measurement and evaluation of natural antioxidant capacity/activity. Pure Appl Ch. 2013;85(5):957-98.

13. Suzuki YJ, Tsuchiya M, Wassal SR, Choo YM, Govil G, Kegan VE, et al. Structural and dynamic membrane properties of a-tocopherol and a-tocotrienol implications to the molecular mechanism of their antioxidant potency. Biochem. 1993;32:10692-9.

14. Kumar S, Pandey AK. Chemistry and biological activities of flavonoids: an overview. Scientific World J. 2013:1-16.

15. Heasley $\mathrm{BH}$. Potent antiproliferative activity of steroidal natural products is mediated by oxysterol-binding proteins. [blog] 6 March 2012. Available at: <http://modernsteroid.blogspot.com/2012/03/potent-antiproliferative-activityof.html> Accessed 29 October 2014.

16. Marrone A, Tran WT. Cytotoxic agents and radiation therapy: mechanisms of action and clinical applications. J Radiother Pract. 2015;14(1):63-9.

17. Kim SH, Choi KC. Anti-cancer effect and underlying mechanism(s) of kaempferol, a phytoestrogen, on the regulation of apoptosis in diverse cancer cell models. Toxicol Res. 2013;29(4):229-34.

\section{PICTORIAL ABSTRACT}

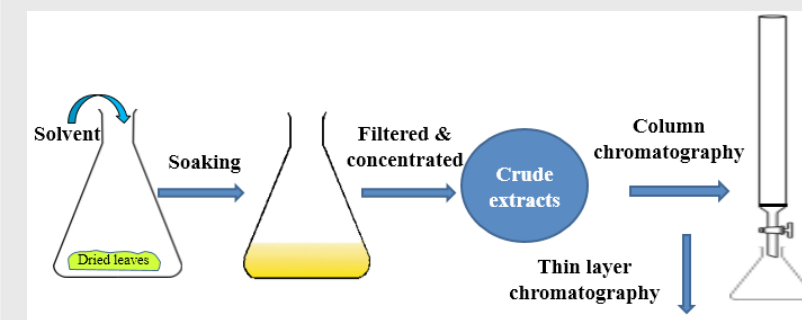

Bioassays: Antioxidant \& Cytotoxic

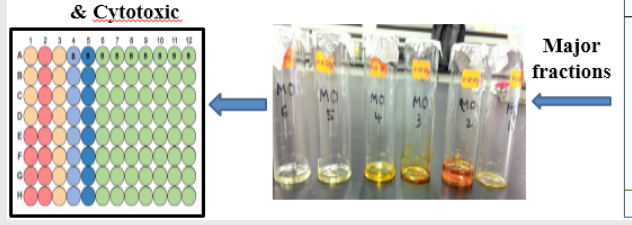

\section{About Authors}

\section{SUMMARY}

- The leaves of Stenochlaena palustris were soaked in various organic solvents at room temperature with occasional shaking.

- The leaves were extracted using cold solvent technique. The crude extracts obtained were further isolated using gravity column chromatography.

- The major fractions were visualized using thin layer chromatography.

- These fractions were further evaluated for antioxidant activity and cytotoxic effect.

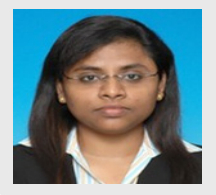

Miss Sangeetha Arullappan: She is a lecturer and Researcher at Department of Biomedical Science, Faculty of Science, Universiti Tunku Abdul Rahman (UTAR), Perak, Malaysia. She has few research articles to her credit and she has been active as Reviewer for international journals. Her area of interest is Medicinal Chemistry and Natural Products, Antimicrobial and Cancer studies.

Cite this article: Arullappan S, Sawai S, Chee LA, Mahandan M, Shanmugavelan R. Phytochemical Screening and Evaluation of Cytotoxic Effect and Antioxidant Activity of Fractions Isolated from Stenochlaena Palustri (Burm.f.) Bedd. Leaves. Indian J of Pharmaceutical Education and Research. 2017;51(4S):S735-S40. 